Paideusis

\title{
International Symposium Concluded: A Reply to Horvath
}

\section{Volodar V. Kraevskii}

Volume 3, Number 1, 1989

URI: https://id.erudit.org/iderudit/1073402ar

DOI: https://doi.org/10.7202/1073402ar

See table of contents

Publisher(s)

Canadian Philosophy of Education Society

\section{ISSN}

0838-4517 (print)

1916-0348 (digital)

Explore this journal

Cite this article

Kraevskii, V. (1989). International Symposium Concluded: A Reply to Horvath. Paideusis, 3(1), 3-3. https://doi.org/10.7202/1073402ar viewed online.

https://apropos.erudit.org/en/users/policy-on-use/ 


\section{International Symposium Concluded}

\section{A Reply to Horvath}

\section{Volodar V. Kraevskii, Academy of Pedagogical Sciences of the USSR}

Evaluating differences between Western and Eastern approaches to education is not easy. The paradigm of evaluation itself is changing rapidly. In our country, a difficult, but inspiring, process of re-evaluating the whole system of human relations (perestroika) is going on. The drawbacks characteristic of societal life during the period of stagnation must be done away with. These include the loss of intellectual initiative, dogmatism, and the break between words and deeds. In the last few years, a new socio-political atmosphere of openness, freedom, creativity, and discussion, and objective, unbiased research has arisen.

We feel the necessity of reconsidering the theory and practice of education in its relation to society in the spirit of the new thinking emerging now. The centrepiece of the new thinking is a new role for universally shared values. It is becoming now the pivot of practical policy and educational thought. 'Horvath's idea of seeking something the traditional theories (Western as well as Eastern) reject not only does not exclude the possibility of finding the points they both accept, but rather presupposes such a possibility. Omni negatio est determinatio! The search for a positive approach to bridge-building on our side might be centered around the following concrete points suggested by perestroika: humanization, focusing on the child's personality as the highest social value; differentiation and individualization, creating conditions for the complete development of each school child's abilities; democratization, creating the necessary prerequisites for the development of activity, initiative, and creativity both of the students and the teachers, and their emotional interaction.

Teachers who try to produce a feeling of freedom of choice in schoolchildren should be encouraged. The main feature of a process of instruction aimed at this is the establishment of an overall process of instruction which must be run within a framework of co-operation with the children as a joint creative effort. The characteristics of this approach would include the following. Conditions must be created for freedom of choice among teaching materials which have the same educational, but different subjective value. Independent creative and constructive activities must be awakened, shaped, and encouraged.

As to the state-society relationship, much is being done to overcome the "smudging of distinctions" about which Horvath writes. One of the tasks of the political reform in the USSR is to give the widest possible scope to selfgovernment in the society and to create favourable conditions to encourage as much initiative as possible by individuals and representative public organizations.

As a result of deformations and distortions in the past, alienation of school from society occurred. The school with all it contained--including teachers and pupils--was made to belong to and work for the state only. The children's interests and the requirements of the society gradually were forced out of the school. Now new concepts of general secondary education are aimed at mending the situation.

Bridge-building is hard work and the way between the two shores cannot be short and very straight. But where there is a will, there is a way. 